\title{
Astrogliosis in the Neonatal and Adult Murine Brain Post-Trauma: Elevation of Inflammatory Cytokines and the Lack of Requirement for Endogenous Interferon- $\gamma$
}

\author{
Maria Rostworowski, ${ }^{1}$ Vijayabalan Balasingam,, ${ }^{1}$ Sophie Chabot, ${ }^{1,2}$ Trevor Owens, $^{1}$ and Voon Wee Yong ${ }^{1,2}$ \\ ${ }^{1}$ Montreal Neurological Institute, McGill University, Montreal, Quebec H3A 2B4, Canada, and 'Neuroscience Research \\ Group, University of Calgary, Calgary NW, Alberta T2N 4N1, Canada
}

\begin{abstract}
The relevance of astrogliosis remains controversial, especially with respect to the beneficial or detrimental influence of reactive astrocytes on CNS recovery. This dichotomy can be resolved if the mediators of astrogliosis are identified. We have measured the levels of transcripts encoding inflammatory cytokines in injury systems in which the presence or absence of astrogliosis could be produced selectively. A stab injury to the adult mouse brain using a piece of nitrocellulose (NC) membrane elicited a prompt and marked increase in levels of transcripts for interleukin (IL)- $1 \alpha$, IL-1 $\beta$, and tumor necrosis factor (TNF)- $\alpha$, which are considered to be microglia/macrophage cytokines. The elevations preceded, or occurred concomitantly with, the rise in glial fibrillary acidic protein $\mathrm{mRNA}$, an early manifestation of astrogliosis. In neonatal mice, IL-1 and TNF- $\alpha$ mRNA were elevated to a greater extent by an NC-implant injury, which produced astrogliosis, than after an NC-stab, with minimal astrogliosis.
\end{abstract}

We determined whether endogenous interferon (IFN)- $\gamma$ could be responsible for the observed increases in IL- 1 and TNF- $\alpha$, because IFN- $\gamma$ is a potent microglia/macrophage activator, and because its exogenous administration to rodents enhanced astrogliosis after adult or neonatal insults. A lack of requirement for endogenous IFN- $\gamma$ was demonstrated by three lines of evidence. First, no increase in IFN- $\gamma$ transcripts could be found at injury. Second, the administration of a neutralizing antibody to IFN- $\gamma$ did not attenuate astrogliosis. Third, in IFN- $\gamma$ knockout adult mice, astrogliosis and increases in levels of IL- $1 \alpha$ and TNF- $\alpha$ were induced rapidly by injury. The marked elevation of inflammatory cytokines is discussed in the context of astrogliosis and general CNS recovery.

Key words: CNS trauma; cytokines; gliosis; interleukin-1; interferon- $\gamma$; microglia; reactive astrocytes; TNF- $\alpha$
A prominent consequence of injury to the adult CNS is astrogliosis, in which reactive astrocytes undergo hypertrophy and increase their content of several proteins (for review, see Eddleston and Mucke, 1993). The glial "scars" that can result may inhibit regeneration or become the focus of electrical instability (for review, see Reier, 1986). More recent evidence, however, suggests that the process of astrocyte reactivity actually may be beneficial for CNS recovery (for review, see Yong, 1996). This dichotomy of reactive astrocytes as impediments or facilitators of CNS recovery can be examined more thoroughly if the molecular mediators of astrogliosis are identified. The hope would be that the manipulation of such mediators would affect the occurrence, extent, or duration of astrogliosis so that the resultant neurotrophic consequences are defined.

Injury to the adult CNS leads to the recruitment of intrinsic (e.g., microglia) and extrinsic (e.g., macrophages, lymphocytes, and natural killer cells) inflammatory mononuclear cells that release diffusable cytokine products; indeed, the levels of interleukin (IL)-1, IL-6, transforming growth factor (TGF)- $\beta$, and tumor necrosis factor (TNF)- $\alpha$ are elevated in the adult brain

Received Jan. 6, 1997; revised Feb. 18, 1997; accepted Feb. 24, 1997.

This work was supported by the Medical Research Council of Canada. We thank M. Krakowski and L. Bourboniere for skilled technical assistance.

Correspondence should be addressed to Dr. Voon Wee Yong, Neuroscience Research Group, Departments of Oncology and Clinical Neurosciences, University of Calgary, 3330 Hospital Drive, Calgary NW, Alberta T2N 4N1, Canada.

Copyright (C) 1997 Society for Neuroscience 0270-6474/97/173664-11\$05.00/0 after CNS trauma (Woodroofe et al., 1991; Taupin et al., 1993; Rimaniol et al., 1995; Lausch et al., 1996).

The presence of increased levels of inflammatory cytokines in the brain raises the question of whether these can produce astrogliosis in post-traumatic brain injuries. This is possible, because the administration of IL-1 (Giulian et al., 1988) into the adult rodent brain increased the extent of astrogliosis. Interferon (IFN)- $\gamma$, a potent stimulator of microglia/macrophages, enhanced the extent of astroglial reactivity in the corticectomized adult rat brain (Yong et al., 1991). On the other hand, the application of IL-10, a potent inhibitor of cytokine synthesis, into the corticectomized adult mouse brain reduced astrogliosis (Balasingam and Yong, 1996).

Results of trauma to the neonatal CNS further support the role of inflammatory cytokines as regulators of astrogliosis. In contrast to adult CNS injury, the presentation of astrogliosis is minimal after stab wounds to the embryonic or neonatal CNS (Bignami and Dahl, 1976; Berry et al., 1983; Maxwell et al., 1990). The minimal astrogliosis, however, becomes extensive when inflammatory cytokines, including IFN- $\gamma$, are administered locally to neonates at the time of stab wound injury (Balasingam et al., 1994). Astrogliosis can also be elicited in neonatal animals when, instead of an acute stab wound, a piece of nitrocellulose (NC) membrane is implanted for $4 \mathrm{~d}$ into the cerebral cortex (Balasingam et al., 1994). In both the NC-stab and NC-implant injury paradigms, with minimal and extensive astrogliosis, respectively, a significant correlation is found between astrogliosis and the presence of reactive microglia/macrophages (Balasingam et al., 1996). 


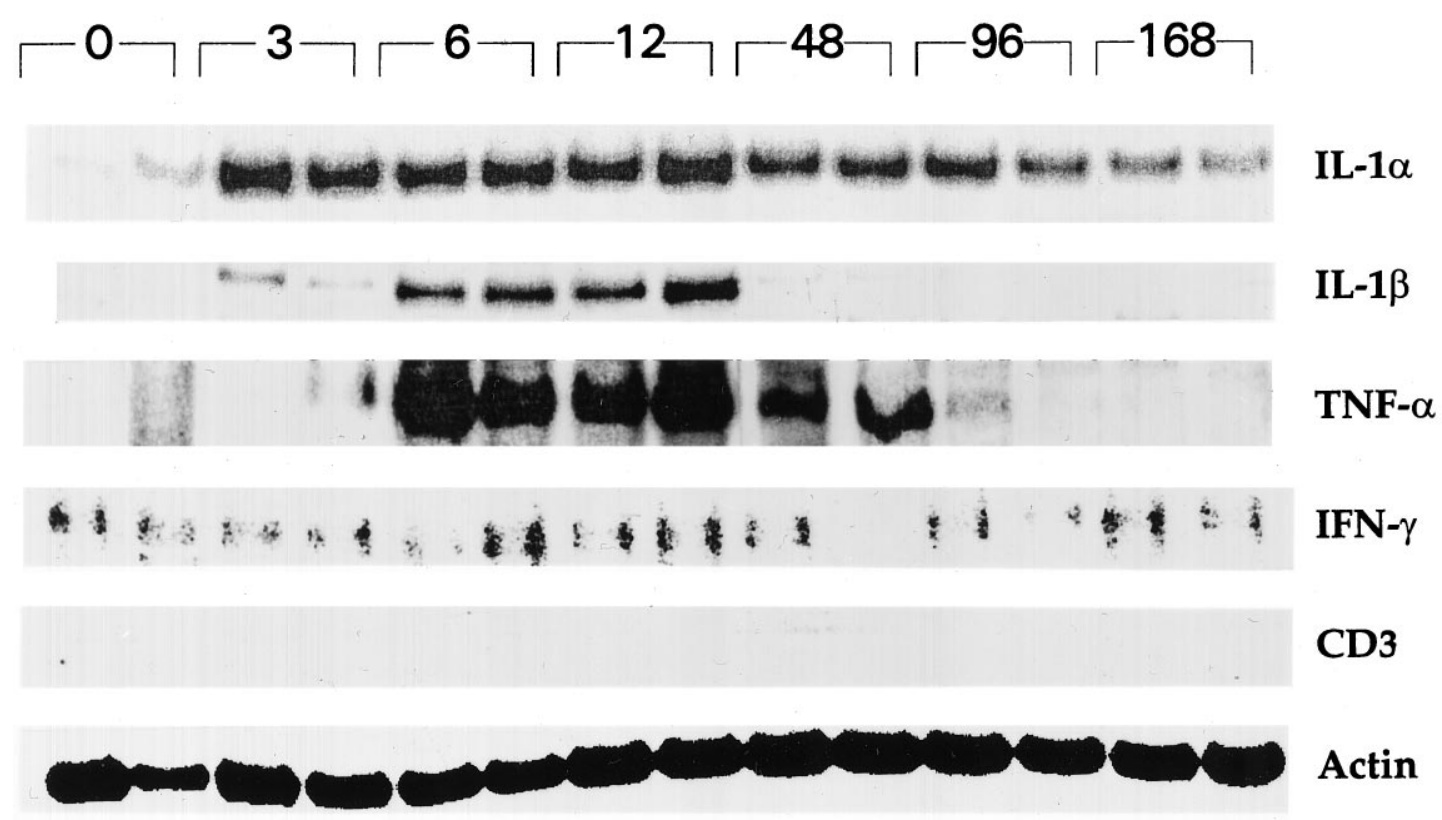

Figure 1. Elevations of inflammatory cytokine transcripts after CNS trauma in adult mice. PCR cDNA products for $I L-1 \alpha, I L-1 \beta, T N F-\alpha, I F N-\gamma, C D 3 \gamma$, and Actin at different periods after an NC-stab injury to the adult brain are shown. The time points are indicated in numerals above the blots and represent hours after injury. Samples from two animals in each group are shown and are from tissues (20 mg wet weight) immediately surrounding the lesion site. The respective sizes of the PCR products are shown in Table 1. For IFN- $\gamma$, the positive hybridization signal control is shown on the extreme right; it represents the amplified product from $0.05 \mu \mathrm{g}$ of total RNA from E9D4 T cells.

In this report, we have sought to define further the role of inflammatory cytokines as mediators of the astrogliosis that follows CNS trauma, by measuring the levels of transcripts encoding inflammatory cytokines in both the adult and neonatal brain subjected to CNS trauma. Furthermore, although the exogenous administration of IFN- $\gamma$ enhances astrogliosis after adult (Yong et al., 1991) or neonatal (Balasingam et al., 1994) insults, we have examined whether endogenous IFN- $\gamma$ is necessary for the elevations of inflammatory cytokines and astrogliosis in the brain after CNS trauma.

\section{MATERIALS AND METHODS}

Experimental animals. Newborn mice (of either sex from natural litters) and adult retired female breeders of the CD1 strain (4-6 months old) were obtained from a commercial source (Charles River Canada, Montreal, Quebec, Canada). Animals were housed on a $12 \mathrm{hr}$ light/dark cycle with ad libitum access to food and water. All experimental procedures were approved by the institution's animal care committee and were in accordance with the guidelines instituted by the Canadian Council of Animal Care.

Neonatal NC-stab and NC-implant unilateral injuries were conducted on the left hemisphere, as described previously (Balasingam et al., 1994) In brief, postnatal day (P) 3 CD1 mouse pups were subjected to inhalational methoxyflurane anesthesia, and the skin overlying the skull was then cut with a scalpel. The soft skull was cut with a pair of fine iris-scissors, and a dry $1 \mathrm{~mm}^{2}$ piece of NC membrane (pore size $8 \mu \mathrm{m}$; Schleicher \& Schuell, Keene, NH) that was boiled previously to remove surfactant was inserted into the cortex. For all NC-stab injuries, the NC membrane was removed immediately, whereas for the NC-implant injury, the NC membrane was left in the cerebral cortex of the animal for the duration of the experiment (see Results).

For adult brain injuries, female CD1 adult mice were anesthetized with ketamine $(200 \mathrm{mg} / \mathrm{kg}$, i.p.) and xylazine $(10 \mathrm{mg} / \mathrm{kg}$, i.p.). The animals were immobilized in a stereotaxis frame, and then a midline incision and a unilateral circular ( $2 \mathrm{~mm}$ diameter) craniectomy were made over the left hemisphere. An NC-stab injury was inflicted as described for neonates but with a larger $\left(4 \mathrm{~mm}^{2}\right)$ piece of NC; only NC-stab was used because the NC-stab and NC-implant injuries in adult mice gave comparable astrogliosis (Balasingam et al., 1994), unlike the case for neonatal animals.
To help determine the requirement for endogenous IFN- $\gamma$ in astrogliosis, $\gamma$-IFN knockout (GKO) mice with a targeted disruption of the IFN- $\gamma$ gene (Dalton et al., 1993) were used. These animals were backcrossed five generations onto a BalbC background and were maintained as homozygous GKO, as described previously (Krakowski and Owens, 1996). GKO female mice of 2 months of age were inflicted with an NC-stab injury as described above. Animals were killed at defined time points thereafter (see Results).

Qualitative assessment of glial fibrillary acidic protein (GFAP) immunoreactivity in situ. All animals were euthanized by $\mathrm{CO}_{2}$ at $4 \mathrm{~d}$ postsurgery, because this is a period when astrogliosis as determined by immunoreactivity for GFAP, a cytoplasmic intermediate filament specific for astrocytes, is markedly elevated (Moumdjian et al., 1991; Balasingam et al., 1996). Neonatal and adult animals were deeply anesthetized with inhalational methoxyflurane or a lethal dose of intraperitoneal chloral hydrate, respectively, and intracardially perfused with periodate-lysineparaformaldehyde (PLP) solution (Balasingam and Yong, 1996). The whole brain was removed from the animal, post-fixed for $6 \mathrm{hr}$ in PLP, and then soaked in $25 \%$ sucrose overnight for cryoprotection. Ten micrometer coronal sections were obtained on gelatin-coated slides and subjected to immunofluorescence for GFAP. In brief, sections were air-dried for 10 min, and after they were washed with PBS, each section was treated for $2 \mathrm{hr}$ with $3 \%$ ovalbumin (Sigma, St. Louis, MO) as a blocking step before incubation with a rabbit anti-GFAP polyclonal antibody (1:100; Dako, Carpenteria, CA) for $6 \mathrm{hr}$ at room temperature. After a brief rinse with PBS, a goat anti-rabbit immunoglobulin conjugated to fluorescein isothiocyanate (1:75; Jackson ImmunoResearch, West Grove, PA) was introduced for $1 \mathrm{hr}$. Negative control for immunohistochemistry was replacement of the primary antibody with the diluting medium for antibody, HHG (i.e., $10 \%$ goat serum, $2 \%$ horse serum, 1 mM HEPES buffer in HBSS). This was followed by a brief rinse in PBS and a final water rinse before mounting with Gelvatol. Slides were coded so that the qualitative assessment of GFAP immunoreactivity (GFAP-IR) could be performed blind. Examination was restricted to the cortical regions, because astrocytes in these areas, unlike those in the external glia limitans and corpus callosum, are normally not GFAP-IR, although they contain this intermediate filament protein (Bignami and Dahl, 1976). The area of the cortex containing GFAP-IR astrocytes was qualitatively tabulated from + to ++++ in ascending order of cortical area covered by GFAP-IR astrocytes.

Reverse transcriptase-PCR (RT-PCR) to measure the transcript levels 


\begin{tabular}{|c|c|c|c|}
\hline $\begin{array}{l}\text { Target } \\
\text { mRNA }\end{array}$ & Forward $(\mathrm{F})$ and reverse $(\mathrm{R})$ primers & $\begin{array}{l}\text { Expected } \\
\text { product size } \\
\text { (base pairs) }\end{array}$ & Reference \\
\hline $\mathrm{IL}-1 \alpha$ & $\begin{array}{l}\text { F: 5'-AAGTTTGTCATGAATGATTCCCTC-3' } \\
\text { R: 5'-GTCTCACTACCTGTGATGAGT-3' }\end{array}$ & 263 & Lomedico et al., 1984 \\
\hline IL- $1 \beta$ & $\begin{array}{l}\text { F: 5'-CAGGATGAGGACATGAGCACC-3' } \\
\text { R: 5'-CTCTGCAGACTCAAACTCCAC-3' }\end{array}$ & 447 & Gray et al., 1986 \\
\hline TNF- $\alpha$ & $\begin{array}{l}\text { F: 5'-ATGAGCACAGAAAGCATGATC-3' } \\
\text { R: 5'-TACAGGCTTGTCACTCGAATT-3' }\end{array}$ & 276 & Fransen et al., 1985 \\
\hline IFN- $\gamma$ & $\begin{array}{l}\text { F: 5'-TACTGCCACGGCACAGTCATTGAA-3' } \\
\text { R: 5'-GCAGCGACTCCTTTTCCGCTTCCT-3' }\end{array}$ & 405 & Gray and Goeddel, 1983 \\
\hline $\mathrm{CD} 3 \gamma$ & $\begin{array}{l}\text { F: 5'-ATGGAGCAGAGGAAGGGTCTG-3' } \\
\text { R: 5'-TCACTTCTTCCTCAGTTGGTT-3' }\end{array}$ & 549 & Renno et al., 1995 \\
\hline$\beta$-actin & $\begin{array}{l}\text { F: 5'-TGTGATGGTGGGAATGGGTCAG-3' } \\
\text { R: 5'-TTTGATGTCACGCACGATTTCC-3' }\end{array}$ & 514 & Alonso et al., 1986 \\
\hline
\end{tabular}

encoding different inflammatory cytokines. The levels of transcripts encoding particular inflammatory cytokine were determined by a semiquantitative RT-PCR. Total RNA was isolated using Trizol (Life Technologies, Grand Island, NY) from samples resected from around the corticectomy site $(\sim 20 \mathrm{mg}$ wet weight). RNA $(0.5 \mu \mathrm{g})$ was reverse-transcribed and amplified in a single-step process, as described previously (Balasingam and Yong, 1996). In brief, the reaction mixture contained $200 \mu \mathrm{M}$ dNTPs, $1 \mu \mathrm{M}$ primers, $2 \mathrm{mM} \mathrm{MgCl}$, $2 \mathrm{U}$ of AMV RT (Life Technologies), $1 \mathrm{U}$ of TAQ polymerase (Life Technologies), 33 U RNA Guard (Pharmacia Biotech), $1 \times$ PCR buffer (Life Technologies), and $0.5 \mu \mathrm{Ci} / \mathrm{ml} \alpha-{ }^{32} \mathrm{P}-$ dCTP (ICN, Costa Mesa, CA) in a total reaction volume of $50 \mu \mathrm{l}$. Samples were placed in a GENEAmp PCR system 9600 (Perkin-Elmer Cetus, Emeryville, CA) at $50^{\circ} \mathrm{C}$ for 15 min followed sequentially by a cyclic phase at $94^{\circ} \mathrm{C}$ for $45 \mathrm{sec}, 60^{\circ} \mathrm{C}$ for $45 \mathrm{sec}$, and then $72^{\circ} \mathrm{C}$ for $1.5 \mathrm{~min}$ for 35 cycles; this number of cycles was predetermined to be in the linear range of amplification for IL- $1 \alpha$, IL- $1 \beta$, TNF- $\alpha$, and IFN- $\gamma$ (results not shown) when their respective positive control samples were analyzed. The positive control for IL- $1 \alpha$, IL- $1 \beta$, and TNF- $\alpha$ was the mouse macrophage cell line ANA-1, whereas that for IFN- $\gamma$ was the mouse T cell line E9D4. Amplification products were electrophoresed on an $8 \%$ nondenaturing polyacrylamide gel, dried under vacuum, visualized by autoradiography, and analyzed in an objective manner by ImageQuant software on a phosphorimager system. RT-PCR for actin mRNA of each sample was also performed as described in Renno et al. (1995); a 24-cycle PCR was used for actin.

The oligonucleotide primers used for RT-PCR for the various cytokines are shown in Table 1; all primers were purchased from Stratagene (La Jolla, CA).

Treatment of mice with a neutralizing antibody to IFN- $\gamma$. To help determine the requirement for endogenous IFN- $\gamma$ in the evolution of astrogliosis, adult CD1 mice were subjected to corticectomy. A piece of Gelfoam soaked with a defined concentration of purified XMG1.2, a neutralizing antibody to murine IFN- $\gamma$ (Mosmann et al., 1986), was then applied to the corticectomy site for the duration of the experiment, as detailed previously for IL-10 (Balasingam and Yong, 1996). Controls were corticectomized mice overlaid with Gelfoam containing saline. All animals were killed at $4 \mathrm{~d}$ after surgery, and brains were processed for GFAP-IR as described above.

To verify that the XMG1.2 antibody was biologically active, we determined whether this antibody could reverse the antiproliferative effect of murine IFN- $\gamma$ on murine astrocytes in vitro (Yong et al., 1992). Neonatal mouse astrocytes, initiated into culture and seeded onto glass coverslips as described previously (Yong et al., 1992), were incubated with a single concentration $(1000 \mathrm{U} / \mathrm{ml})$ of recombinant murine IFN- $\gamma$ (Genzyme, Boston, MA) for a total of $2 \mathrm{~d}$, with $1 \mu \mathrm{Ci}$ of ${ }^{3} \mathrm{H}$-thymidine added during the last $16 \mathrm{hr}$ of culture. Sister cultures were treated with saline (controls) or were given $1000 \mathrm{U} / \mathrm{ml}$ of IFN- $\gamma$ that had been preincubated for $1 \mathrm{hr}$ at $37^{\circ} \mathrm{C}$ with XMG1.2 antibody at $0.01,0.1,0.5,1$, and $10 \mu \mathrm{g} / \mathrm{ml}$ concentrations. Coverslips were then assessed for ${ }^{3} \mathrm{H}$-thymidine uptake as described (Yong et al., 1992).

\section{RESULTS}

Trauma to the adult brain: elevations of inflammatory cytokines and their relationship to GFAP mRNA

Brain tissues from uninjured mice express low to undetectable levels of cytokine transcripts when measured by RT-PCR using a 35-cycle amplification. In contrast, after injury a rapid elevation of IL-1 $\alpha$, IL-1 $\beta$, and TNF- $\alpha$ becomes evident (Fig. 1). Tabulation of the elevations of cytokines demonstrates that by $3 \mathrm{hr}$ after an $\mathrm{NC}$-stab injury to the adult murine brain, the mRNA encoding IL-1 $\alpha$ was already markedly elevated around the lesion site when compared with uninjured controls (Fig. 2). Levels of mRNA for IL-1 $\beta$ and TNF- $\alpha$ were also altered with peak elevations at 6-12 hr after the induction of CNS trauma.

In previous work (Balasingam et al., 1996), we have noted that the elevation of GFAP mRNA is an early reliable indicator of astrogliosis. Others have noted the increase, by $5 \mathrm{hr}$, of mRNA for c-jun, jun B, and TIS 11 (Haas et al., 1993), but the cellular source of these is unclear. We therefore measured the mRNA for GFAP and found a prominent rise by $6 \mathrm{hr}$ after NC-stab injury, which peaked at $24 \mathrm{hr}$. This rise in GFAP transcript occurs coincident with (IL-1 $\beta$ and TNF- $\alpha$ ) or following (IL- $1 \alpha$ ) the elevations of transcripts encoding inflammatory cytokines (Fig. 2).

In contrast to IL- 1 or TNF- $\alpha$, the levels of IFN- $\gamma$ mRNA remained low to undetectable at all the time points analyzed after the NC-stab injury (Figs. 1, 2). Because a prominent source of IFN- $\gamma$ is T cells, RT-PCR for the CD3 molecule specific for T cells was analyzed; no CD3 was detected in the CNS parenchyma at all examined periods (Fig. 1).

\section{NC-stab or -implant injuries to neonatal mice: levels of inflammatory cytokines}

To confirm previous results (Balasingam et al., 1994) of the minimal astrogliosis after an acute stab injury to neonatal brains, so that injury samples from the same groups of animals can then be used for RT-PCR analyses, GFAP-IR was performed on the neonatal brain at $4 \mathrm{~d}$ postinjury. This time point was chosen because unlike GFAP mRNA the manifestation of GFAP-IR in reactive astrocytes becomes prominent only days after an injury (Moumdjian et al., 1991; Balasingam et al., 1996). In neonates, as in adults, GFAP-IR is a reliable indicator of astrogliosis and correlates with ultrastructural manifestations of reactive astrocytes (Balasingam et al., 1996). Figure 3 demonstrates that the 


\section{Changes In mRNA Levels In The Adult Brain Following A Stab Injury}

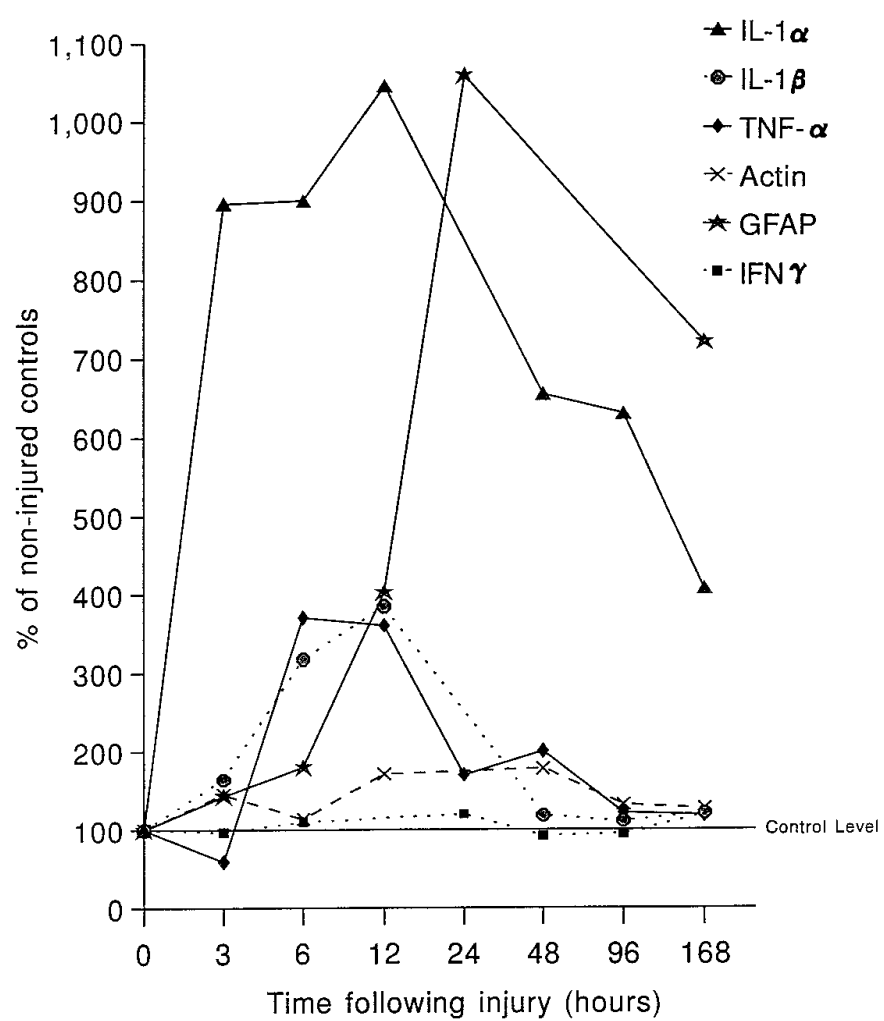

Figure 2. Changes in levels of transcripts encoding inflammatory cytokines and GFAP. The amounts of the PCR cDNA products were obtained from phosphorimager readings of the bands in each blot and were expressed as a ratio to that of their respective control specimens in the same blot. Each value in the graph represents the mean phosphorimager readings from two animals within the same blot; results from other blots using two additional animals from each group resulted in similar findings. Note that the elevation of IL- $1 \alpha$ precedes that of GFAP, whereas those for TNF- $\alpha$ and IL- $1 \beta$ occur at around the same period as that for GFAP transcript. No increase in IFN- $\gamma$ transcript is detected, and actin levels are relatively stable across the different groups to indicate relative similarity in the total RNA content in all groups.

NC-stab injury to the P3 mouse pup creates minimal GFAP-IR $4 \mathrm{~d}$ later. In contrast, the $\mathrm{NC}$-implant injury to neonates generates extensive astrogliosis, as does the NC-stab injury to adult mice.

RNA samples from neonates subjected to NC-implant injury demonstrate significant elevations of IL- $1 \alpha$, IL- $1 \beta$, and TNF- $\alpha$. The rise of cytokine mRNA was noted by $3 \mathrm{hr}$ and peaked at $6 \mathrm{hr}$ after the NC-implant insult (Fig. 4). The NC-stab injury to the neonate also produced elevations of IL- $1 \alpha$ and TNF- $\alpha$ mRNA (Fig. 4), but these were less marked than those found after the NC-implant injury.

In correspondence with the adult brain, the infliction of trauma to the neonatal CNS (stab or implant injury) did not result in elevation of the low levels of IFN- $\gamma$ that is found in the CNS (Fig. 4).

\section{Endogenous IFN- $\gamma$ is not required for the evolution of astrogliosis or for the elevation of inflammatory cytokines}

The exogenous administration of IFN- $\gamma$ after injury to the adult (Yong et al., 1991) or neonatal (Balasingam et al., 1994) brain
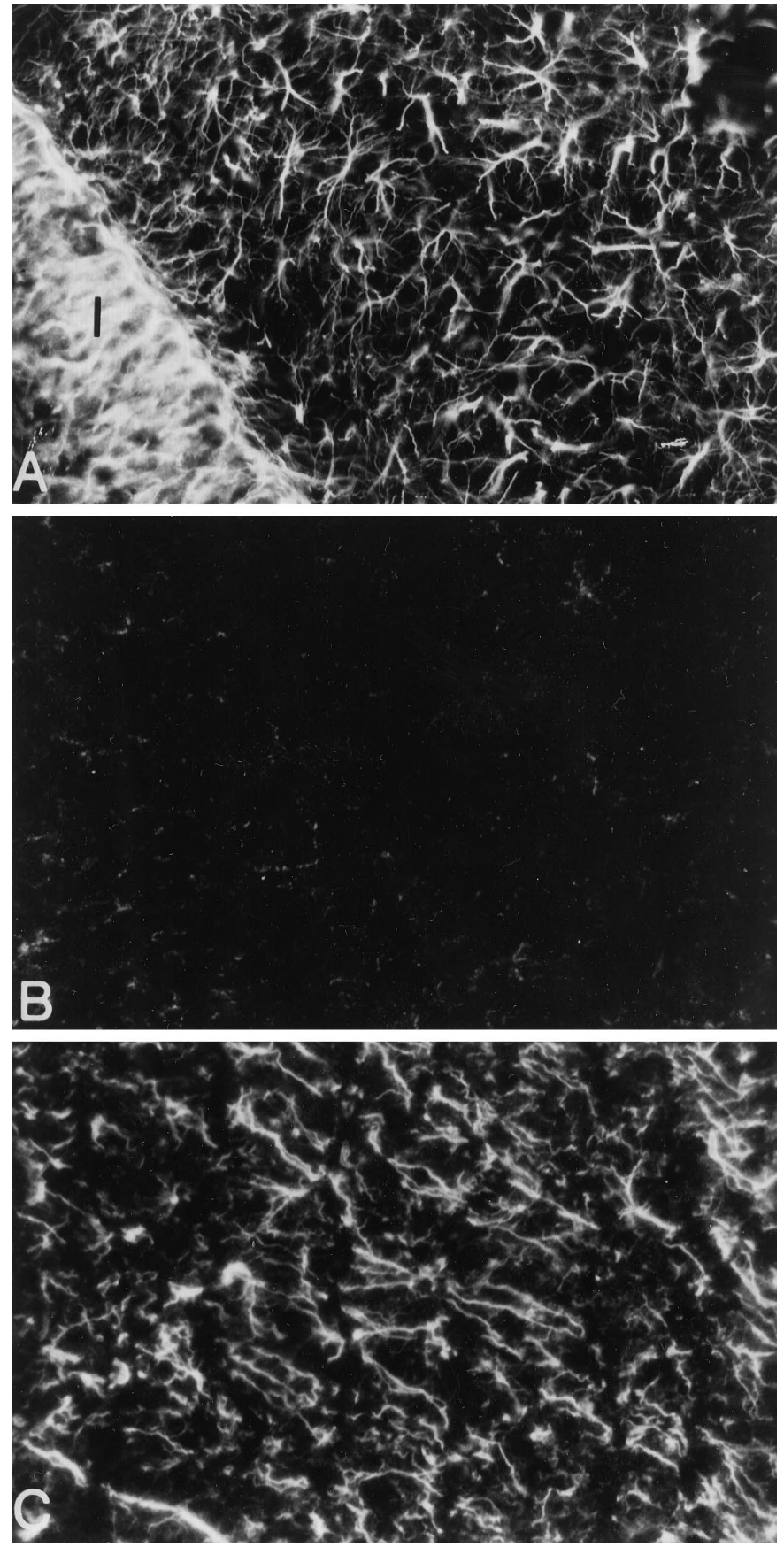

Figure 3. GFAP-IR reveals extensive astrogliosis after NC-implant $(A)$ but not NC-stab $(B)$ injuries to the neonate. In adult mice, an NC-stab injury produces extensive astrogliosis $(C)$. All brain sections were from animals killed at $4 \mathrm{~d}$ after trauma. Areas shown are of the cortical parenchyma, where GFAP-IR is normally absent in the brain of uninjured animals fixed with paraformaldehyde. We note, however, that fixation conditions can influence whether astrocytes can be revealed in the normal cortex (Shebab et al., 1990). The implant in $A$ is indicated by the letter $I$, and the stab site in the neonatal or adult brain is immediately left and outside $B$ and $C .800 \times$ original magnification.

enhances the extent of astrogliosis, likely because IFN- $\gamma$ is a potent activator of several functions of microglia/macrophages, including their production of IL-1 and TNF- $\alpha$ (Williams et al., 1995; Renno et al., 1995). But is endogenous IFN- $\gamma$ required for the evolution of astrogliosis or for the trauma-related increase in levels of macrophage/microglia cytokines? Three approaches 


\section{Changes In mRNA Levels Encoding Inflammatory Cytokines Following Stab $\mathrm{O}_{1}$ Implant Injury To The Neonatal Mouse Brain}
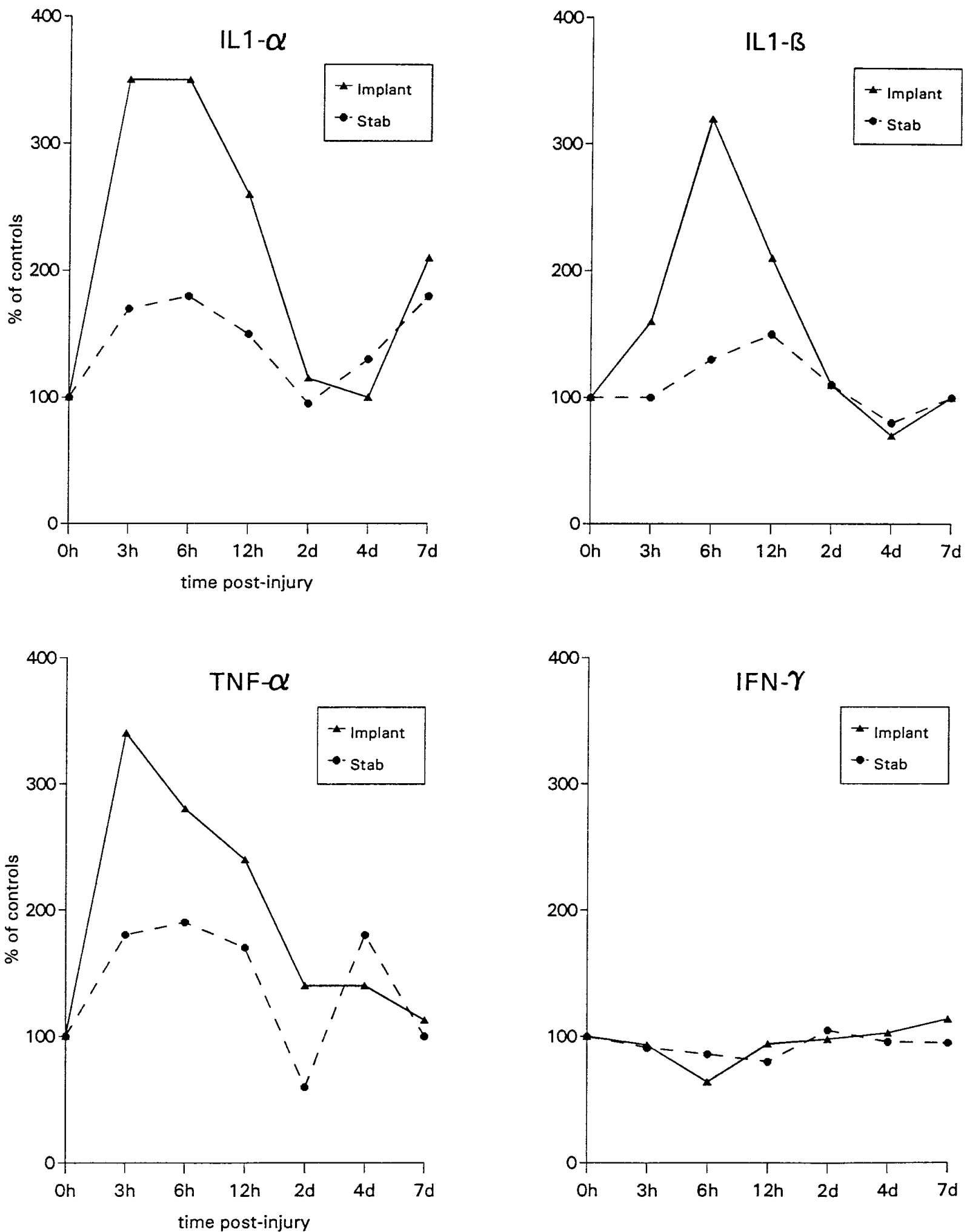

Figure 4. Changes in IL- $1 \alpha$, IL- $1 \beta$, TNF- $\alpha$, and IFN- $\gamma$ in neonatal NC-stab or NC-implant brains at different time points postinjury. Phosphorimager readings of the bands in the respective blots were obtained and expressed as a ratio of that of control specimens. Each value shown is the mean of RNA determinations from two animals. Although a slight increase in IL-1 and TNF- $\alpha$ was elicited after NC-stab injury, the magnitude was less than that found after NC-implant injury. As is the case for adult injury, IFN- $\gamma$ transcripts did not elevate from control levels. 
Table 2. Extent of astrogliosis in CD1 adult mouse brain treated with a neutralizing antibody to IFN- $\gamma$ (XMG)

\begin{tabular}{lc} 
Treatment & Extent of astrogliosis \\
\hline Saline & $4 \pm 0(7)$ \\
XMG & \\
$5 \mu \mathrm{g} / \mathrm{ml}$ & $3.8 \pm 0.3(4)$ \\
$50 \mu \mathrm{g} / \mathrm{ml}$ & $3.8 \pm 0.3(4)$ \\
$100 \mu \mathrm{g} / \mathrm{ml}$ & $3.5 \pm 0.5(4)$ \\
$200 \mu \mathrm{g} / \mathrm{ml}$ & $3.7 \pm 0.2(7)$ \\
$\mathrm{IL}-10$ & $1.8 \pm 0.2(3)^{*}$ \\
$200 \mathrm{IU} / \mathrm{ml}$ &
\end{tabular}

Sections from corticectomized animals treated with gelfoam soaked in test solutions were evaluated blind on a scale of 1 (no gliosis) to 4 (extensive astrogliosis); the number of animals analyzed is shown in parentheses. One section per animal, at the site of corticectomy, was analyzed. Values are mean \pm SEM. As reported previously (Balasingam and Yong, 1996), IL-10, used as a positive control here, attenuated astrogliosis; ${ }^{*} p<0.05$ (one-way ANOVA with Duncan's multiple comparisons, with $p$ set at 0.05 ). Note that the concentrations of XMG administered in gelfoam in vivo are much higher, in most cases, than the concentrations used to neutralize IFN- $\gamma$ bioactivity in vitro (Fig. 6). This is so because preliminary experiments with the concentrations used in vitro had not diminished astrogliosis when applied in gelfoam.

were undertaken to determine this. First, the adult CD1 mouse brain was treated with a neutralizing antibody to IFN- $\gamma$ (XMG1.2) administered in a piece of Gelfoam that overlaid the corticectomy site. Table 2 demonstrates that the treatment with the neutralizing antibody to IFN- $\gamma$ did not attenuate the astrogliosis that follows CNS trauma. That the XMG1.2 antibody was biologically active was confirmed by its neutralization of the inhibitory effect of IFN- $\gamma$ on the proliferation of cultured murine astrocytes (Fig. 5).

The second and third approaches to determine the requirement for IFN- $\gamma$ in the evolution of astrogliosis make use of the GKO animals. Figure 6 demonstrates that the creation of an NC-stab injury to the adult GKO mouse brain results in marked astrogliosis when compared with uninjured GKO controls; this result was reproduced across all animals analyzed (Table 3). Finally, the measurement of cytokine mRNA shows that the transcripts for IL- $1 \alpha$ and TNF- $\alpha$ are elevated markedly after an NC-stab injury to the adult GKO mouse brain (Fig. 7). Overall, these results support the thesis that endogenous IFN- $\gamma$, which does not elevate after CNS trauma to CD1 mouse outbreds (Figs. 2, 4), is not required for the rise in macrophage/microglia cytokines or for the production of astrogliosis in CNS trauma.

\section{DISCUSSION}

The role of reactive astrocytes after injury is unclear. For many types of CNS injuries, the process of astroglial reactivity is dynamic and leads to a densely interwoven "glial scar" that has classically been believed to be undesirable (Reier et al., 1986; Liuzzi and Lasek, 1987). More recent evidence, however, suggests that the process of astroglial reactivity may actually be an attempt by these cells to promote CNS recovery. In this regard, astrocytes

Table 3. Extent of astrogliosis in GKO adult mouse brain with or without a stab injury

\begin{tabular}{ll} 
Group & Extent of astrogliosis \\
\hline No stab & $1 \pm 0(12)$ \\
Stab & $4 \pm 0(12)$
\end{tabular}

Four sections per animal, from three animals each, were analyzed using GFAP immunofluorescence, and the extent of astrogliosis was evaluated on a scale of 1 (no gliosis) to 4 (extensive astrogliosis); the total number of sections analyzed is shown in parentheses. produce a range of neurotrophic factors and are conducive substrates for the growth of neurons in vitro and in vivo (Lindsay, 1979; Silver and Ogawa, 1983; Noble et al., 1984; Smith et al., 1986). We have found that astrocytes facilitate the extension of processes from the oligodendrocyte soma (Oh and Yong, 1996), an early event in myelinogenesis, and also protect oligodendrocytes against free radical-mediated damage (Noble et al., 1994).

In vivo results have also contributed to the description of beneficial properties for reactive astrocytes. Neurotrophic factors are produced around the locus of CNS lesions, and although earlier studies did not identify the source of these factors (NietoSampedro et al., 1982, 1983; Needels et al., 1986; Ernfors et al., 1989; Ishikawa et al., 1991; Lindvall et al., 1994), more recent studies have documented the upregulation of nerve growth factor (NGF) (Bakhit et al., 1991; Altar et al., 1992; Oderfeld-Nowak et al., 1992; Arendt et al., 1995), ciliary neurotrophic factor (Ip et al., 1993; Asada et al., 1995; Wen et al., 1995), basic fibroblast growth factor (Finklestein et al., 1988; Frautschy et al., 1991; GomezPinilla et al., 1995; Wen et al., 1995), and insulin-like growth factor-1 (Komoly et al., 1992) in reactive astrocytes.

Other results also support the postulate that reactive astrocytes have neurotrophic properties. Kawaja and Gage (1991) implanted primary fibroblasts genetically engineered to express NGF into the striatum of adult rats. Cholinergic neurons arising from the nucleus basalis grew toward and penetrated these grafts but did not penetrate non-NGF-producing control fibroblasts. Significantly, axons grew into grafts of NGF-producing cells only on reactive astrocyte processes. In other experiments, a nitrocellulose filter embedded with early postnatal astrocytes and implanted into previously acallosal mice provided a terrain suitable for axons to traverse the cerebral midline to reform a corpus callosum (Silver and Ogawa, 1983; Smith et al., 1986). The implantation of astrocytes into adult rats with CNS lesions has resulted in the recovery of T-maze learning behavior (Kesslak et al., 1986; Bradbury et al., 1995) and an increase in the intensity of neurofilament labeling at the lesion site (Wang et al., 1995).

To better address the role of reactive astrocytes in facilitating or impeding regeneration, an understanding of the molecular mediator(s) of astroglial reactivity and the ability to manipulate its occurrence and extent would be beneficial. Several lines of evidence support a role for inflammatory cytokines as mediators of astrogliosis. Receptors for IFN- $\gamma$, IL-1, IL-6, IL-7, IL-10, granulocyte macrophage colony stimulating factor (GM-CFS), and macrophage colony stimulating factor (M-CSF) have been demonstrated on astrocytes (Rubio and de Felipe, 1991; Ban et al., 1993; Sawada et al., 1993; Mizuno et al., 1994; Tada et al., 1994; St. Pierre et al., 1996). The administration of IL-1 (Giulian et al., 1988) and IFN- $\gamma$ (Yong et al., 1991) into the adult rodent brain increased the extent of astrogliosis. The intraocular injections of IFN- $\gamma$, TNF- $\alpha$, and IL-1 evoked astrogliosis in rabbits (Brosnan et al., 1989). Transgenic mice that overexpress IL-6 (Chiang et al., 1994) or IFN- $\gamma$ (Corbin et al., 1996) within the CNS have astrogliosis as a prominent manifestation. In neonatal mice in which an acute stab injury generates little astrogliosis, the application of a single dose of various inflammatory cytokines produces extensive astrogliosis (Balasingam et al., 1994). Gelderd et al. (1996) reported recently that the administration of an IL-1 receptor antagonist protein substantially reduced the number of reactive astrocytes at the site of spinal cord transection. We have found that the treatment of adult mice with IL-10, a cytokine synthesis inhibitor (de Waal Malefyt et al., 1991; Fiorentino et al., 1991), will significantly attenuate astrogliosis (Balasingam and Yong, 1996). 


\section{Reversal Of The Inhibitory Proliferative Effects Of IFN- $\boldsymbol{\gamma}$ By The Neutralising Antibody XMG1.2}

Figure 5. The XMG1.2 antibody neutralizes the activity of IFN- $\gamma$ in vitro. As reported previously (Yong et al., 1992), IFN- $\gamma$ inhibits the proliferation of neonatal mouse astrocytes in a dose-dependent manner. Here, a single concentration of 1000 $\mathrm{U} / \mathrm{ml}$ recombinant murine IFN- $\gamma$ was applied to neonatal mouse astrocytes for $48 \mathrm{hr}$, and ${ }^{3} \mathrm{H}$-thymidine was determined. The inhibitory effect of IFN- $\gamma$ on the proliferation of neonatal mouse astrocytes was reversed by $0.5-10.0 \mu \mathrm{g} / \mathrm{ml}$ of XMG antibody. The hatched columns to the right demonstrate that the XMG antibody by itself did not affect cell proliferation. Each bar is the mean \pm SEM of four coverslips of cells. $p<0.05$ compared with IFN- $\gamma$ alone (one-way ANOVA with Duncan's multiple comparisons, with $p$ set at 0.05 ).

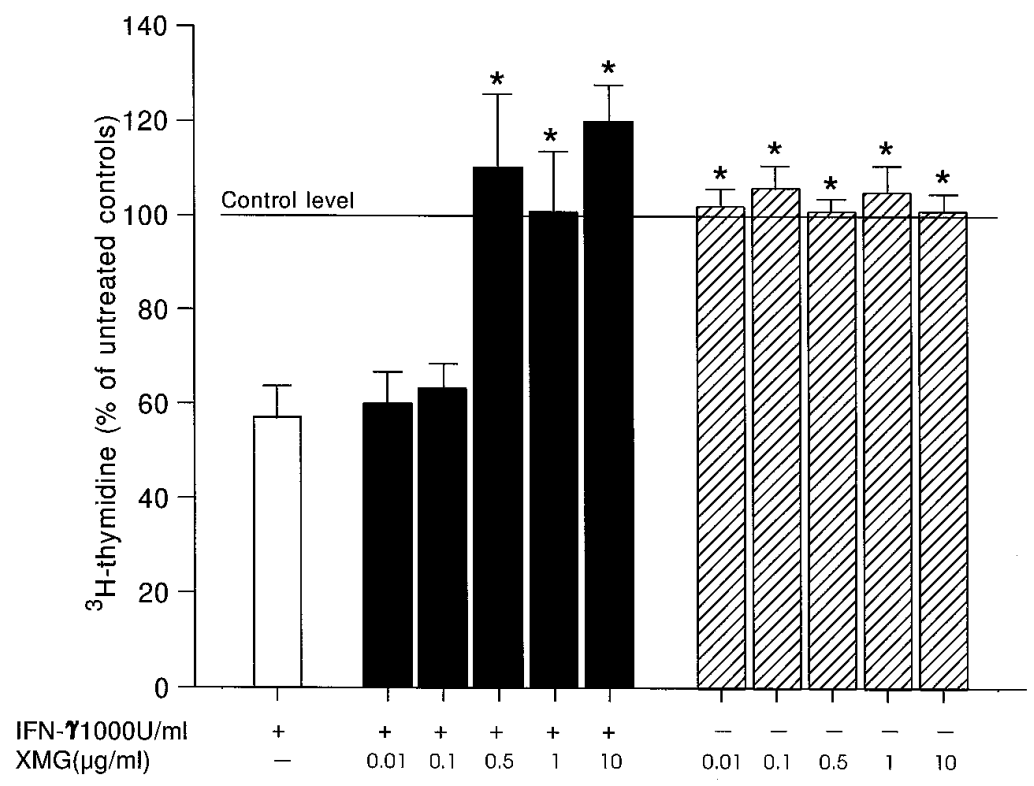

The results in this manuscript provide further insights into the role of inflammatory cytokines as mediators of astrogliosis. First, IL- $1 \alpha$, IL- $1 \beta$, and TNF- $\alpha$ are markedly elevated after a stab wound to the adult CNS, confirming the reports of others in adult trauma (Woodroofe et al., 1991; Taupin et al., 1993; Rimaniol et al., 1995; Lausch et al., 1996). Second, we show that the increase in mRNA for inflammatory cytokines occurs coincident with or precedes the rise in GFAP mRNA, an early indicator of astrogliosis. Third, we demonstrate that in neonatal animals, the rise in transcripts for inflammatory cytokines is more marked after an NC-implant injury with extensive astrogliosis when compared with the NC-stab injury with minimal astrogliosis. To our knowledge, this is the first report of elevations of inflammatory cytokines in the neonatal CNS after trauma.

We note that both the NC-implant and NC-stab injuries to neonates led to increases in the mRNA for inflammatory cytokines. It is possible that the extent of rise of cytokines in the $\mathrm{NC}$-stab injury does not reach a threshold that is required for the evolution of astrogliosis. Furthermore, we note that the greater elevation of transcripts after the NC-implant injury is the result of a very short duration of the implant in vivo (i.e., $<3 \mathrm{hr}$ ).

What are the sources of the inflammatory cytokines that are elevated after CNS trauma? T lymphocytes seem unlikely, because CD3 mRNA did not increase in the CNS parenchyma after trauma (Fig. 1). We favor the thesis that microglia/macrophages are the source of the elevated inflammatory cytokines, because IL-1 and TNF- $\alpha$ are cytokines that are known to be produced by cells of the mononuclear phagocyte lineage. Furthermore, previous work had suggested the requirement for reactive microglia/ macrophages in the evolution of astrogliosis (Balasingam et al., 1996). The attenuation of astroglial reactivity by IL-10 was associated with a decrease in Mac-1 immunoreactivity of microglia/ macrophages (Balasingam and Yong, 1996). Nonetheless, other possible sources, including astrocytes and neurons, cannot be disregarded, because these neural cells have been documented to express a number of inflammatory cytokines under particular conditions (for review, see Yong, 1996). It is clear that the source of inflammatory cytokines shortly after CNS trauma needs to be determined.

What is responsible for the elevation of inflammatory cytokines that follow CNS trauma? One possibility is IFN- $\gamma$, a potent activator of several functions of microglia/macrophages, which can enhance astrogliosis after CNS trauma (Yong et al., 1991; Balasingam et al., 1994); in vitro, IFN- $\gamma$ can cause microglia to secrete IL-1 and TNF- $\alpha$ (Williams et al., 1995). The results of this study, however, exclude the involvement of endogenous IFN- $\gamma$, because no elevation of this cytokine could be detected after injury to both the adult and neonatal CNS. Furthermore, in GKO mice without any IFN- $\gamma$ gene expression, astrogliosis and elevations of IL- $1 \alpha$ and TNF- $\alpha$ could still be produced. It would be interesting to explore other stimuli that elevate inflammatory cytokines post-trauma. These stimuli could include alterations of the extracellular matrix (ECM) after mechanical trauma, because ECM components can affect several microglia properties (Xing et al., 1992; Sievers et al., 1994; Monning et al., 1995), various ions, given the multiplicity of ion channels in microglia (Ilschner et al., 1995), or nucleotides/nucleosides (Neary et al., 1996). Chemokines with cell-activating properties may also be candidates, because monocyte chemoattractant protein-1 is also rapidly elevated after trauma to the neonatal and adult murine CNS (Glabinski et al., 1996).

It should be added that the elevation of IFN- $\gamma$ has been noted in the brain in disease states; however, these tend to be autoimmune disorders such as experimental allergic encephalomyelitis (Kennedy et al., 1992; Issazadeh et al., 1995) rather than acute trauma. The earlier finding that IFN- $\gamma$ is expressed in neurons after axotomy (Olsson et al., 1989) is tempered by the report that the molecule is related to, but is not, immune IFN- $\gamma$ (Kiefer et al., 1991).

The marked elevation of inflammatory cytokines post-trauma has several implications for CNS recovery. In addition to their potential role as mediators of astrogliosis, inflammatory cytokines 


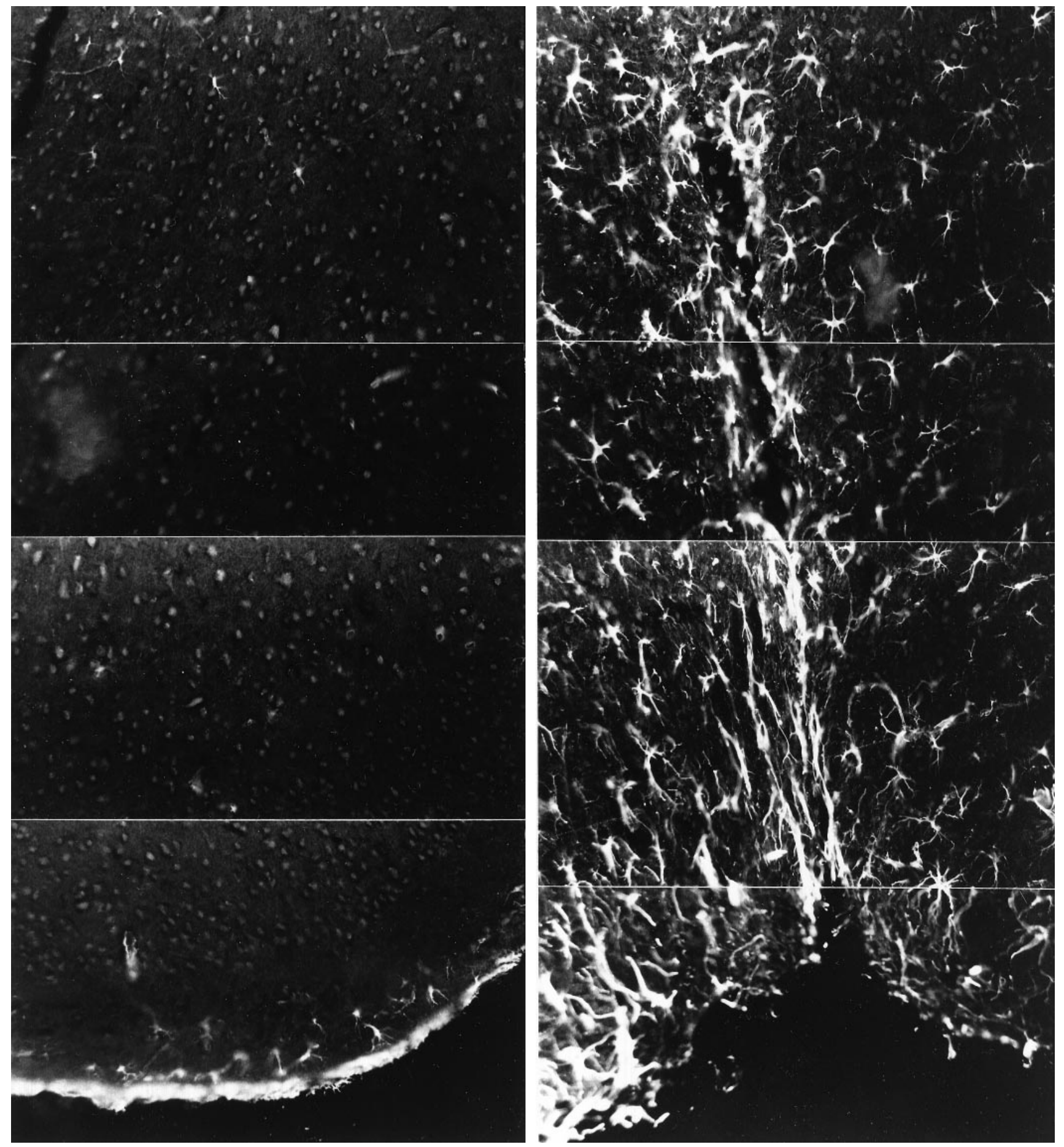

Figure 6. Astrogliosis is readily produced in GKO adult mice after a stab injury. GFAP-IR at $4 \mathrm{~d}$ after an NC-stab injury to the cortex shows extensive astrogliosis (right); in contrast, the uninjured GKO adult mouse cortex (left) contains no GFAP-IR cells except in the glia limitans (bottom). Each panel is the montage of four frames at $800 \times$ original magnification. The stab site, shown in the right panels, is seen as an indentation in the outer surface of the cortex.

may affect neuronal well-being. Several inflammatory cytokines have been shown in vitro to increase the survival of neurons or to promote neurite extension by several populations of purified neurons (for review, see Mehler et al., 1996; Yong, 1996). David et al. (1990) showed that the nonpermissive nature of the isolated rat optic nerve in vitro could become permissive to ingrowth of neurites from dorsal root ganglia if the optic nerve sections were treated with macrophages isolated from injured brains. In vivo, the application of TNF- $\alpha$ to the injured adult rabbit optic nerve has been reported to produce regeneration of axons that could traverse the site of injury (Schwartz et al., 1993). The administration of IL-3 (Kamegai et al., 1993) or GM-CSF (Konishi et al., 1993) after fimbria- fornix transection in rats promoted the survival of septal cholinergic neurons. As noted earlier, tissue ex- 


\section{IL- $1 \alpha$ And TNF- $\alpha$ Are Also Elevated Following A Stab Wound Injury To GKO Mice}

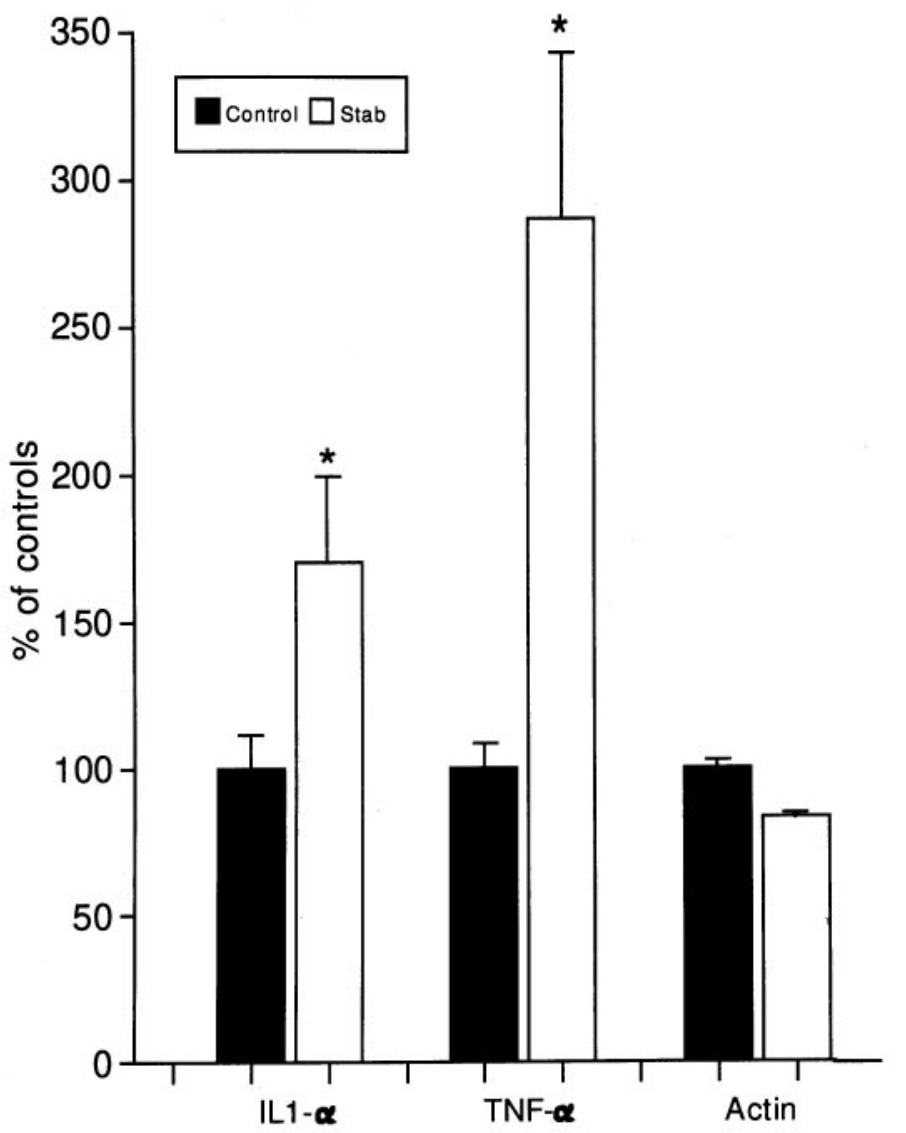

Figure 7. The absence of the IFN- $\gamma$ gene in GKO mice does not prevent the rise in IL- $1 \alpha$ and TNF- $\alpha$ mRNA after CNS trauma. Tissue from around the NC-stab site was dissected at $3 \mathrm{hr}$ after an NC-stab injury to GKO adults. Each band represents the cDNA product from a single GKO mouse, whereas the histograms are the pooled mean \pm SEM from groups of four animals. As predicted, no IFN- $\gamma$ transcripts were detected, whereas a positive control RNA sample, from the E9D4 T cell line that produces IFN- $\gamma$, gave a strong band (results not shown). $p<0.05$ compared with uninjured controls (one-way ANOVA with Duncan's multiple comparisons, with $p$ set at 0.05$)$.

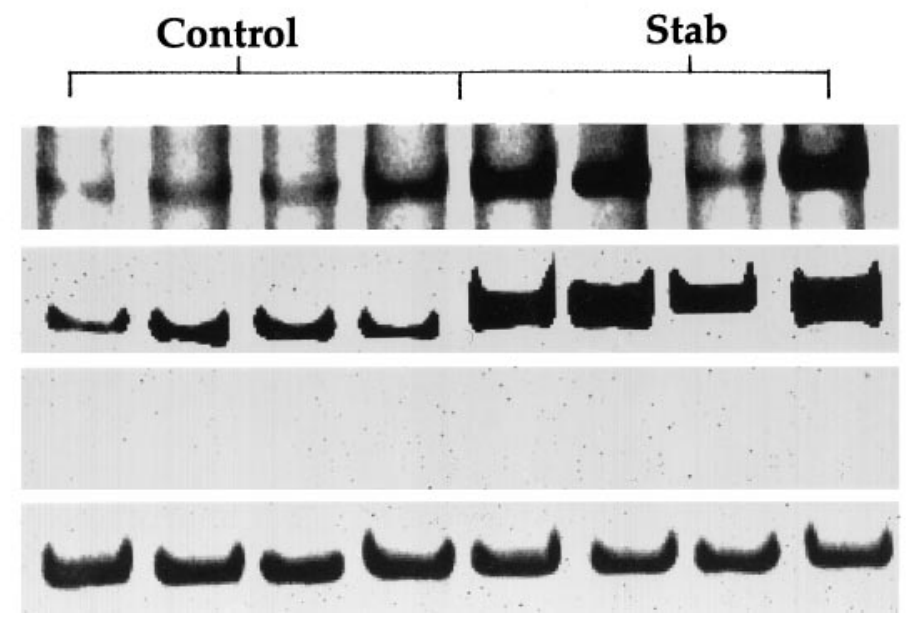

IL-1 $\alpha$

TNF- $\alpha$

IFN- $\gamma$

Actin

tracts collected from around CNS lesion sites support the survival and growth of neurons in vitro (Nieto-Sampedro et al., 1982, 1983; Kesslak et al., 1986; Needels et al., 1986). Although Ip et al. (1993) demonstrated that a candidate neurotrophic factor in these injury extracts is ciliary neurotrophic factor, it remains to be assessed systematically whether and to what degree inflammatory cytokines contribute to the neurotrophic activity that is found in injury extracts.

In addition to the mediation of astrogliosis and their direct neurotrophic potential, inflammatory cytokines can regulate the produc- tion of several neurotrophic factors. The injection of IL-1 into the brains of animals increased NGF levels locally (Spranger et al., 1990; Oderfeld-Nowak et al., 1992). DeKosky et al. (1996) reported that the NGF increase after a stab wound injury in rats was blocked by an IL-1 receptor antagonist. In tissue culture experiments, the synthesis of NGF by astrocytes was enhanced by treatment with IL-1, IL-4, IL-5, IL-6, and TNF- $\alpha$ (for review, see Yong, 1996).

In conclusion, inflammatory cytokines are elevated not only in the CNS of adult animals after CNS mechanical trauma, but they also are elevated in neonatal animals, associated with astrogliosis. 
Endogenous IFN- $\gamma$ is not necessary for the increase of inflammatory cytokines, even though the exogenous administration of IFN- $\gamma$ will cause astrogliosis, likely through the activation of microglia/macrophages to release cytokines. The presence of inflammatory cytokines can be important in influencing CNS regeneration, either by direct neurotrophic actions, by causing astrocytes to become reactive, and/or by affecting the neurotrophic activity of astrocytes. It is possible that under certain conditions, inflammatory cytokines become impairments to the recovery of the CNS; for instance, TNF- $\alpha$ can be toxic to oligodendrocytes (Louis et al., 1993; D’Souza et al., 1996). Understanding and regulating the activities of inflammatory cytokines within the CNS constitutes a key step toward effecting CNS recovery.

\section{REFERENCES}

Alonso S, Minty A, Bourlet Y, Buckingham M (1986) Comparison of three actin-coding sequences in the mouse: evolutionary relationships between the actin genes of warm-blooded vertebrates. J Mol Evol 23:11-22.

Altar CA, Armanini M, Duggich-Djordjevic M, Bennett GL, Williams R, Feinglass S, Anicetti V, Sinicropi D, Bakhit C (1992) Recovery of cholinergic phenotype in the injured rat neostriatum: roles for endogenous and exogenous nerve growth factor. J Neurochem 59:2167-2177.

Arendt T, Bruckner MK, Krell T, Pagliusi S, Kruska L, Heumann R (1995) Degeneration of rat cholinergic basal forebrain neurons and reactive changes in nerve growth factor expression after chronic neurotoxic injury. II. Reactive expression of NGF gene in astrocytes. Neuroscience 65:647-659.

Asada H, Ip NY, Pan L, Razack N, Parfitt MM, Plunkett RJ (1995) Time course of ciliary neurotrophic factor mRNA expression is coincident with the presence of protoplasmic astrocytes in traumatized rat striatum. J Neurosci Res 40:22-30.

Bakhit C, Armanini M, Bennett GL, Wong WLT, Hansen SE, Taylor R (1991) Increase in glia-derived nerve growth factor following destruction of hippocampal neurons. Brain Res 560:76-83.

Balasingam V, Yong VW (1996) Attenuation of astroglial reactivity by interleukin-10. J Neurosci 16:2945-2955.

Balasingam V, Tejada-Berges T, Wright E, Bouckova R, Yong VW (1994) Reactive astrogliosis in the neonatal mouse brain and its modulation by cytokines. J Neurosci 14:846-856.

Balasingam V, Dickson K, Brade A, Yong VW (1996) Astrocyte reactivity in neonatal mice: apparent dependence on the presence of reactive microglia/macrophages. Glia 18:11-26.

Ban EM, Sarlieve LL, Haour FG (1993) Interleukin-1 binding sites on astrocytes. Neuroscience 52:725-733.

Bradbury EJ, Kershaw TR, Marchbanks RM, Sinden JD (1995) Astrocyte transplants alleviate lesion induced memory deficits independently of cholinergic recovery. Neuroscience 65:955-972.

Berry M, Maxwell WL, Logan A, Mathewson A, McConnell P, Ashburst DE, Thomas GH (1983) Deposition of scar tissue in the central nervous system. Acta Neurochir [Suppl] (Wien) 32:31-53.

Bignami A, Dahl D (1976) The astroglial response to stabbing: immunofluorescence studies with antibodies to astrocyte-specific protein (GFA) in mammalian and submammalian vertebrates. Neuropathol Appl Neurobiol 2:99-110.

Brosnan CF, Litwak MS, Schroeder CE, Selmaj K, Raine CS, Arezzo JC (1989) Preliminary studies of cytokine-induced functional effects on the visual pathways in the rabbit. J Neuroimmunol 25:227-239.

Chiang CS, Stalder A, Samimi A, Campbell IL (1994) Reactive gliosis as a consequence of interleukin-6 expression in the brain: studies in transgenic mice. Dev Neurosci 16:212-221.

Corbin JG, Kelly D, Ruth EM, Baerwald KD, Suzuki K, Popko B (1996) Targeted CNS expression of interferon- $\gamma$ in transgenic mice leads to hypomyelination, reactive gliosis, and abnormal cerebellar development. Mol Cell Neurosci 7:354-370.

Dalton DK, Pitts-Meek S, Keshav S, Figari IS, Bradley A, Stewart TA (1993) Multiple defects of immune cell function in mice with disrupted interferon- $\gamma$ genes. Science 259:1739-1742.

David S, Bouchard C, Tsatas O, Giftochristos N (1990) Macrophages can modify the nonpermissive nature of the adult mammalian central nervous system. Neuron 5:463-469.

DeKosky ST, Styren SD, O’Malley ME, Goss JR, Kochanek P, Marion D, Evans CH, Robbins PD (1996) Interleukin-1 receptor antagonist sup- presses neurotrophin response in injured rat brain. Ann Neurol 39:123-127.

D'Souza SD, Alinauskas KA, Antel JP (1996) Ciliary neurotrophic factor selectively protects human oligodendrocytes from tumor necrosis factor-mediated injury. J Neurosci Res 43:289-298.

de Waal Malefyt R, Abrams J, Bennett B, Figdor CG, de Wries JE (1991) Interleukin 10 (IL-10) inhibits cytokine synthesis by human monocytes: an autoregulatory role of IL-10 produced by monocytes. J Exp Med 174:1209-1220.

Eddleston M, Mucke L (1993) Molecular profile of reactive astrocytes: implications for their role in neurologic disease. Neuroscience 54:15-36.

Ernfors P, Henschen A, Olson L, Persson H (1989) Expression of nerve growth factor receptor mRNA is developmentally regulated and increased after axotomy in rat spinal cord motoneurons. Neuron 2:1605-1613.

Finklestein SP, Apostolides PJ, Caday CG, Prosser J, Philips MF, Klagsbrun M (1988) Increased basic fibroblast growth factor (bFGF) immunoreactivity at the site of focal brain wounds. Brain Res 460:253-259.

Fiorentino DF, Zlotnik A, Mosmann TR, Howard M, O'Garra AO (1991) IL-10 inhibits cytokine production by activated macrophages. J Immunol 147:3815-3822.

Fransen L, Muller R, Marmenout A, Tavernier J, van der Heyden J, Kawashima E, Chollet A, Tizard R, van Heuverswyn H (1985) Molecular cloning of mouse tumor necrosis factor cDNA and its eukaryotic expression. Nucleic Acids Res 13:4417-4429.

Frautschy SA, Walicke PA, Baird A (1991) Localization of basic fibroblast growth factors and its mRNA after CNS injury. Brain Res 553:291-299.

Gelderd JB, Hall NRS, Ogrady MP, Oliver J, Ferrer C, Anderson JA (1996) The effects of interleukin-1 receptor antagonist protein (IRAP) infusion following spinal cord transection in rats. Mol Chem Neuropathol 27:167-183.

Giulian D, Woodward J, Young DG, Krebs JF, Lachman LB (1988) Interleukin-1 injected into mammalian brain stimulates astrogliosis and neovascularization. J Neurosci 8:2485-2490.

Glabinski AR, Balasingam V, Tani M, Kunkel SL, Strieter RM, Yong VW, Ransohoff RM (1996) Chemokine monocyte chemoattractant protein-1 is expressed by astrocytes after mechanical injury to the brain. J Immunol 156:4363-4368.

Gomez-Pinilla F, Vu L, Cotman CW (1995) Regulation of astrocyte proliferation by FGF-2 and heparan sulfate in vivo. J Neurosci 15:2021-2029.

Gray PW, Goeddel DV (1983) Cloning and expression of murine interferon cDNA. Proc Natl Acad Sci USA 80:5842-5846.

Gray PW, Glaister D, Chen E, Goeddel DV, Pennica D (1986) Two interleukin 1 genes in the mouse: cloning and expression of the cDNA for murine interleukin 1 beta. J Immunol 137:3644-3648.

Haas CA, Donath C, Kreutzberg GW (1993) Differential expression of immediate early genes after transection of the facial nerve. Neuroscience 53:91-99.

Ilschner S, Ohlemeyer C, Gimpl G, Kettenmann H (1995) Modulation of potassium currents in cultured murine microglial cells by receptor activation and intracellular pathways. Neuroscience 66:983-1000.

Ip NY, Wiegand SJ, Morse J, Rudge JS (1993) Injury-induced regulation of ciliary neurotrophic factor mRNA in the adult rat brain. Eur J Neurosci 5:25-33.

Ishikawa R, Nishikori K, Furukawa S (1991) Appearance of nerve growth factor and acidic fibroblast growth factor with different time courses in the cavity-lesioned cortex of the rat brain. Neurosci Lett 127:70-72.

Issazadeh S, Mustafa M, Ljungdahl A, Hojeberg B, Dagerlind A, Elde R, Olsson T (1995) Interferon gamma, interleukin 4 and transforming growth factor beta in experimental autoimmune encephalomyelitis in Lewis rats: dynamics of cellular mRNA expression in the central nervous system and lymphoid cells. J Neurosci Res 40:579-590.

Kamegai M, Niijima K, Kunishita T, Nishizawa M, Ogawa M, Araki M, Ueki A, Konishi Y, Tabira T (1990) Interleukin 3 as a trophic factor for central cholinergic neurons in vitro and in vivo. Neuron 4:429-436.

Kawaja MD, Gage FH (1991) Reactive astrocytes are substrates for the growth of adult CNS axons in the presence of elevated levels of nerve growth factor. Neuron 7:1019-1030.

Kennedy MK, Torrance DS, Picha KS, Mohler KM (1992) Analysis of cytokine mRNA expression in the central nervous system of mice with experimental autoimmune encephalomyelitis reveals that IL-10 mRNA expression correlates with recovery. J Immunol 149:2496-2505.

Kesslak JP, Nieto-Sampedro M, Globus J, Cotman CW (1986) Transplants of purified astrocytes promote behavioral recovery after frontal cortex ablation. Exp Neurol 92:377-390. 
Kiefer R, Kaas CA, Kreutzberg GW (1991) Gamma-interferon-like immunoreactive material in rat neurons: evidence against a close relationship to gamma-interferon. Neuroscience 45:551-560.

Komoly S, Hudson LD, deF Webster H, Bondy CA (1992) Insulin-like growth factor I gene expression is induced in astrocytes during experimental demyelination. Proc Natl Acad Sci USA 89:1894-1898.

Konishi Y, Chui D-H, Hirose H, Kunishita T, Tabira T (1993) Trophic effect of erythropoietin and other hematopoietic factors on central cholinergic neurons in vitro and in vivo. Brain Res 609:29-35.

Krakowski M, Owens T (1996) Interferon-gamma confers resistance to experimental allergic encephalomyelitis. Eur J Immunol 26:1641-1646.

Lausch RN, Chen SH, Tumpey TM, Su YH, Oakes JE (1996) Early cytokine synthesis in the excised mouse cornea. J Interferon Cytokine Res 16:35-40.

Lindsay RM (1979) Adult rat brain astrocytes support survival of both NGF-dependent and NGF-insensitive neurones. Nature 282:80-82.

Lindvall O, Kokaia Z, Bengzon J, Elmer E, Kokaia M (1994) Neurotrophins and brain insults. Trends Neurosci 17:490-496.

Liuzzi FJ, Lasek RJ (1987) Astrocytes block axonal regeneration in mammals by activating the physiological stop pathway. Science 237:642-645.

Lomedico PT, Gubler U, Hellmann CP, Dukovich M, Giri JG, Pan YC, Collier K, Semionow R, Chua AO, Mizel SB (1984) Cloning and expression of murine interleukin-1 cDNA in Escherichia coli. Nature 312:458-462.

Louis J-C, Magal E, Takayama S (1993) CNTF protection of oligodendrocytes against natural and tumor necrosis factor $\alpha$-induced death Science 259:689-692.

Maxwell WL, Follows R, Ashhurst DE, Berry M (1990) The response of the cerebral hemisphere of the rat to injury. II. The neonatal rat. Philos Trans R Soc Lond [Biol] 328:501-513.

Mehler MF, Goldstein H, Kessler JA (1996) Effects of cytokines on CNS cells: neurons. In: Cytokines and the CNS (Ransohoff RM, Benveniste EN, eds), pp 115-150. Boca Raton, FL: CRC.

Mizuno T, Sawada M, Marunouchi T, Suzumura A (1994) Production of interleukin-10 by mouse glial cells in culture. Biochem Biophys Res Commun 205:1907-1915.

Monning U, Sandbrink R, Weidemann A, Banati RB, Masters CL, Beyreuther K (1995) Extracellular matrix influences the biogenesis of amyloid precursor protein in microglial cells. J Biol Chem 270:7104-7110.

Mosmann TR, Cherwinski H, Bond MW, Giedlin MA, Coffman RL (1986) Two types of murine helper T cell clone. I. Definition according to profiles of lymphokine activities and secreted proteins. J Immunol 136:2348-2357.

Moumdjian RA, Antel JP, Yong VW (1991) Origin of contralateral reactive gliosis in surgically injured rat cerebral cortex. Brain Res 547:223-228.

Neary JT, Rathbone MP, Cattabeni F, Abbracchio MP, Burnstock G (1996) Trophic actions of extracellular nucleotides and nucleosides on glial and neuronal cells. Trends Neurosci 19:13-18.

Needels DL, Nieto-Sampedro M, Cotman CW (1986) Induction of a neurite-promoting factor in rat brain following injury or deafferentation. Neuroscience 18:517-526.

Nieto-Sampedro M, Lewis ER, Cotman EW, Manthrope M, Skaper SD, Barbin G, Longo FM, Varon S (1982) Brain-injury causes a timeindependent increase in neurotrophic activity at the lesion site. Science 217:860-861

Nieto-Sampedro M, Manthrope M, Barbin G, Varon S, Cotman CW (1983) Injury-induced neuronotrophic activity in adult rat brain: correlation with survival of delayed implants in the wound cavity. J Neurosci 3:2219-2229.

Noble M, Fok-Seang J, Cohen J (1984) Glia are a unique substrate for the in vitro growth of central nervous system neurons. J Neurosci 4:1892-1903.

Noble PG, Antel JP, Yong VW (1994) Astrocytes and catalase prevent the toxicity of catecholamines to oligodendrocytes. Brain Res 633:83-90.

Oderfeld-Nowak B, Bacia A, Gradkowska M, Fusco M, Vantini G, Leon A, Aloe L (1992) In vivo activated brain astrocytes may produce and secrete nerve growth factor-like molecules. Neurochem Int 21:455-461.

Oh LYS, Yong VW (1996) Astrocytes promote process outgrowth by adult human oligodendrocytes in vitro through interaction between bFGF and astrocyte extracellular matrix. Glia 17:237-253.

Olsson T, Kristensson K, Ljungdahl A, Maehlen J, Holmdahl R, Klares$\operatorname{kog} \mathrm{L}(1989) \gamma$-Interferon-like immunoreactivity in axotomized rat motor neurons. J Neurosci 9:3870-3875.
Reier PJ (1986) Gliosis following CNS injury: the anatomy of astrocytic scars and their influences on axonal elongation. In: Astrocytes, Vol 3 (Fedoroff S, Vernadakis A, eds), pp 263-324. New York: Academic.

Renno T, Krakowski M, Piccirillo C, Lin JY, Owens T (1995) TNF- $\alpha$ expression by resident microglia and infiltrating leukocytes in the central nervous system of mice with experimental allergic encephalomyelitis: regulation by Th1 cytokines. J Immunol 154:944-953.

Rimaniol AC, Lekieffre D, Serrano A, Masson A, Benavides J, Zavala F (1995) Biphasic transforming growth factor-beta production flanking the pro-inflammatory cytokine response in cerebral trauma. NeuroReport 7:133-136.

Rubio N, de Felipe C (1991) Demonstration of the presence of a specific interferon- $\gamma$ receptor on murine astrocyte cell surface. J Neuroimmunol 35:111-117.

Sawada M, Itoh Y, Suzumura A, Marunouchi T (1993) Expression of cytokine receptors in cultured neuronal and glial cells. Neurosci Lett 160:131-134.

Schwartz M, Solomon A, Lavie V, Ben-Bassat S, Belkin M, Cohen A (1993) Tumor necrosis factor facilitates regeneration of injured central nervous system axons. Brain Res 545:334-338.

Shebab SAS, Cronly-Dillon JR, Nona SN, Stafford CA (1990) Preferential histochemical staining of protoplasmic and fibrous astrocytes in rat CNS with GFAP antibodies using different fixatives. Brain Res 518:347-352.

Sievers J, Parwaresch R, Wottge HU (1994) Blood monocytes and spleen macrophages differentiate into microglia-like cells on monolayers of astrocytes: morphology. Glia 12:245-258.

Silver J, Ogawa MY (1983) Postnatally induced formation of the corpus callosum in acallosal mice in glial-coated cellulose bridges. Science 220:1067-1069.

Smith GM, Miller RH, Silver J (1986) Changing role of forebrain astrocytes during development, regenerative failure, and induced regeneration upon transplantation. J Comp Neurol 251:23-43.

Spranger M, Lindholm D, Bandtlow C, Heumann R, Gnahn H, NaherNoe M, Thoene H (1990) Regulation of nerve growth factor (NGF) synthesis in the rat central nervous system: comparison between the effects of interleukin-1 and various growth factors in astrocyte cultures and in vivo. Eur $\mathrm{J}$ Neurosci 2:69-76.

St Pierre BA, Merrill JE, Dopp JM (1996) Effects of cytokines on CNS cells: glia. In: Cytokines and the CNS (Ransohoff RM, Benveniste EN, eds), pp 151-168. Boca Raton, FL: CRC.

Tada M, Diserens AC, Desbaillets I, de Tribolet N (1994) Analysis of cytokine receptor messenger RNA expression in human glioblastoma cells and normal astrocytes by reverse-transcription polymerase chain reaction. J Neurosurg 80:1063-1073.

Taupin V, Toulmond S, Serrano A, Benavides J, Zavala F (1993) Increase in IL-6, IL-1 and TNF levels in rat brain following traumatic lesion. J Neuroimmunol 42:177-186.

Wang JJ, Chuah MI, Yew DTW, Leung PC, Tsang DSC (1995) Effects of astrocyte implantation into the hemisected adult rat spinal cord. Neuroscience 65:973-981.

Wen R, Song Y, Cheng T, Matthes MT, Yasumura D, Lavall MM, Steinberg RH (1995) Injury-induced upregulation of BFGF and CNTF mRNAs in the rat retina. J Neurosci 15:7377-7385.

Williams KC, Dooley NP, Ulvestad E, Waage A, Blain M, Yong VW, Antel JP (1995) Antigen presentation by human fetal astrocytes with the cooperative effect of microglia or the microglial-derived cytokine IL-1. J Neurosci 15:1869-1878.

Woodroofe MN, Sarna GS, Wadha M, Hayes GM, Loughlin AJ, Tinker A, Cuzner ML (1991) Detection of interleukin-1 and interleukin-6 in adult rat brain, following mechanical injury, by in vivo microdialysis: evidence of a role for microglia in cytokine production. J Neuroimmunol 33:227-236.

Xing Z, Jordana M, Gauldie J (1992) IL-1 beta and IL-6 gene expression in alveolar macrophages: modulation by extracellular matrices. Am J Physiol 265:600-605.

Yong VW (1996) Cytokines, astrogliosis, and neurotrophism following CNS trauma. In: Cytokines and the CNS (Ransohoff R, Benveniste E, eds), pp 309-327. Boca Raton, FL: CRC.

Yong VW, Moumdjian R, Yong FP, Ruijs TCG, Freedman MS, Cashman N, Antel JP (1991) Gamma-interferon promotes proliferation of adult human astrocytes in vitro and reactive gliosis in the adult mouse brain in vitro. Proc Natl Acad Sci USA 88:7016-7020.

Yong VW, Tejada-Berges T, Goodyer CG, Antel JP, Yong FP (1992) Differential proliferative response of human and mouse astrocytes to gamma-interferon. Glia 6:269-280. 